\title{
Nurture Santri Pondok Pesantren of Riyadlul Jannah Ciseeng Bogor Research and Development Center for Religious and Religious Education, Ministry of Religion Research and Development Agency and Training Agency
}

\author{
Munawiroh $^{1}$, Achmadudin $^{2}$, Saridudin $^{3}$, Suryadi $^{4}$ \\ \{mun.asrori@gmail.com ${ }^{1}, \underline{\text { achmad.dudin@gmail.com }}{ }^{2}$, dudinsaridudin@gmail.com ${ }^{3}$, \\ hcsuryadi.unj@gmail.com ${ }^{4}$ \}
}

Ministry of Religious Affairs of the Republic of Indonesia ${ }^{123}$, State University of Jakarta 4

\begin{abstract}
This study aims to determine the parenting patterns of students at the Riyadlul Jannah Ciseeng Islamic Boarding School, Bogor. The shift in parenting patterns from kiai to caregivers, mudir, ustadz and mudabbir must be done considering the increasing number of parents entrusting pesantren to be a safe educational institution for their children. This raises new problems for pesantren in terms of the patterns of parenting for students. This research is a field research, in which the researcher goes directly to digging data in the field by means of observation, interviews, distributing questionnaires, and literature study. The direction of the research broadly leads to meeting or dialogue between the care system applied in the pesantren and the influence on the formation of the personality of the students. The result of this research is that the parenting pattern at Riyadlul Jannah Islamic Boarding School applies democratic parenting from the teaching aspect, authoritarian from the reward aspect and persuasive from the persuasion aspect. Teaching is given through intra, extra-curricular activities. Reward through reward or motivation and punishment. Persuasion is done by giving advice through an individual approach to help students solve their problems.
\end{abstract}

Keywords: Riyadlul Jannah Islamic Boarding School, Parenting, Santri

\section{Introduction}

Islamic boarding school is an educational and teaching institution for students based on Islamic teachings with the aim of worship to get the pleasure of Allah SWT. The students are educated to become true believers, namely humans who fear Allah SWT. have a noble character, have complete personal integrity, are independent and have intellectual qualities. In the Islamic boarding school, the students learn to live in society, organize, lead and be led. They are also required to be able to obey and serve their lives in all things. In addition, one must be willing to carry out any task assigned by the caretakers. [1]

Dhofier stated that the basic elements that make up the boarding school institution are the kiai, mosque, dormitory, santri and the yellow book. The element is placed in a central position in the pesantren community, because it is considered the owner, manager and teacher of the yellow book as well as the priest (leader) at religious ritual events, such as performing congregational prayers. Meanwhile, the other elements, namely the 
mosque, dormitory, santri and the yellow book are subsidies whose existence is under the control and supervision of the kiai. The physical characteristics that distinguish Islamic boarding schools and educational institutions outside the Islamic boarding schools lie in this element. [2]

The subculture that is built by the boarding school community is always in a larger socio-cultural system. Islamic boarding schools form a religious tradition that operates within the socio-cultural frame of a pluralistic and complex society. The larger social system tends to suppress small communities that are still within its sphere of influence. Although the religious tradition of Islamic boarding schools can build a subculture, the pesantren itself is an inseparable part of society's culture. Islamic boarding schools (Islamic boarding schools) are educational institutions that have existed and are rooted in Indonesian society long before the birth of the school system introduced by the Dutch colonial government. [3]

In the past Islamic boarding schools have no doubt succeeded in educating students to become pious and highly moral people, a quality that cannot be ignored by people who yearn for tranquility and peace in their lives. Islamic boarding schools are one of the traditional Islamic educational institutions in Indonesia. This predicate is associated by Kuntowijoyo with main characteristics, namely curriculum, learning methods, and institutions. [4]

The curriculum in this connection has a whole Islamic religious lesson content coupled with learning tools, especially Arabic, to understand texts. religion in its original language which aims to create and develop a Muslim personality, study, deepen, appreciate, and practice Islamic teachings by emphasizing the importance of religious morals as guidelines for daily behavior. Nowadays, many parents think about the processing system for santri care in the Islamic boarding school environment. They believe more in the nurturing system that the boarding school provides. Basically, the care that is carried out in a boarding school environment has various specific patterns. From several references and the results of previous research, this santri parenting activity has three patterns, namely authoritarian patterns, permissive patterns and democratic patterns. [5]

These three patterns in practice in Islamic boarding schools are often used in educating students. This authoritarian pattern basically means that parents or caregivers have full authority to regulate their students and these students must obey. The permissive pattern emphasizes the freedom of the students, the role of caregivers in this pattern is not as strong as in the first pattern. Democratic patterns are more inclined to the principle of harmony between the wishes of parents and students. The role of the caregiver is to control and supervise the students and the relationship between the two is closer. This aims to train the independence of students or santri

In the past, the parenting style applied in dormitories tended to be authoritarian or centered on one figure only. Through this style of coaching, it is hoped that students will obey and develop in the direction expected by the boarding school. Authoritarian parenting style affects the condition of students living in Islamic boarding schools when compared to other parenting styles such as permissiveness and democracy. One of the prominent influences is the discipline of students. Therefore, coaches must familiarize students with participating in a series of Islamic boarding school activities and comply with applicable regulations. Strategies to achieve the goal of disciplining students include the example of their caregivers through advice, guidance and ta'zir (punishment). 
Currently, the pattern of parenting that depends on the kiai has shifted. The pattern of parenting is currently shifting to Musyrif, Mudir, and Mudabbir. Due to the progress of the times, and the number of students being cared for, it makes it difficult for kiai to carry out parenting.

Therefore, it is very interesting to conduct research on the parenting patterns of students held at the Riyadlul Jannah Ciseeng Islamic Boarding School, Bogor. A modern Islamic boarding school with a kiai, named KH. Muhammad Supriyadi.

\subsection{Research Problem}

Problem Formulation this study is how the implementation of parenting students at Pondok Pesantren Riyadlul Jannah Ciseeng Bogor

\subsection{Objectives and Benefits of Research}

The purpose of this study was to determine the parenting students at Pondok Pesantren Riyadlul Jannah Ciseeng Bogor

The benefits of this study were: (1) Government: as a policy material in developing the guidance process in Islamic boarding schools; (2) Islamic boarding schools: input into the process of caring for the students at the pesantren so that the pesantren is the best place to produce a superior generation; and (3) Society: provides information about the models of caring for students in Islamic boarding schools so that people can feel comfortable sending them to Islamic boarding schools.

\subsection{Research Methods}

This research was conducted from June to August 2020, located at the Riyadlul Jannah Ciseeng Islamic Boarding School, Bogor.

This research is qualitative in nature because it provides meaning and looks for the essence that it gets from the parenting patterns in the pesantren. In order to carry out the Cross Analysis, this study also uses a quantitative approach to see the behavior of students in the parenting patterns of the pesantren. This research is also a field research, where the researcher goes directly to digging data in the field by means of observation, interviews, distributing questionnaires, literature study, and conducting descriptions in the field to study problems in Islamic boarding schools about changes in values or views, behavior and effects of a phenomenon. The direction of the research broadly leads to meeting or dialogue between the care system applied in the pesantren and the influence on the formation of the personality of the students.

Observations are made on every activity related to research. Interviews with caregivers, pesantren administrators, santri, and other parties related to the pesantren are intended to hear information from them about facts, events they have experienced, and they know. Distribution of questionnaires to students to see the behavior of the students in the parenting patterns at the pesantren. Literature study by examining various literatures, documents and other works related to this research problem.

Data analysis was carried out during data collection in the field and after the data was collected. Data analysis takes place simultaneously which is carried out simultaneously with the data collection process with three analysis processes, namely data reduction, data presentation, data depiction and verification. 


\section{Literature Review}

\subsection{Pondok pesantren}

Pondok pesantren is a unique system, not only unique in its learning approach, but also unique in the way of life and values adopted, the way of life followed, and all other aspects of education and society. From the systematics of teaching, there is a learning system that is repeated from level to level, with no end in sight. The issues taught are often similar discussions repeated over a period of years, even though the textbooks are used differently.

There are traditional methods of learning in pesantren, namely learning methods that are organized according to habits that have long been used in pesantren institutions or are the original learning methods of pesantren. There is also a new learning method ( tajdid), which is a method of learning the results of renewal among pesantren by introducing methods that are developing in modern society. The application of new methods is also followed by the application of a new system, namely the school system or classical. [6]

In its original state, the Islamic boarding school had a non-classical education and teaching system, known as bandungan, sorogan, and wetonan. The implementation of education and teaching differs from one Islamic boarding school to another, in the sense that there is no uniform system in the delivery of education and teaching.

In line with the times, pesantren educational institutions also do not shut themselves off from carrying out both method and technical reforms in the implementation of pesantren education itself. Even so, not all pesantren are willing to open to innovations and innovations to existing learning methods.

At the beginning of the boarding school, the methods used were the methods Islamic boarding schools wetonan and sorogan and bandongan for non-classical. In further developments, the Islamic boarding school learning method tries to renovate the existing method to develop a new method, namely the classical method. The kiai is in charge of teaching various recitations for various levels of teaching in his pesantren, and it is up to the santri to choose which one they will take. [7]

If students want to participate in all types of recitation being taught, of course it will take a long time. However, the entire teaching structure is not determined by the length or shortness of a student's time to recite the Koran at his Kiai, because there is no need to take exams from his Kiai. The only measure used is his submission to the Kiai and his ability to obtain "ngelmu" from the Kiai. [8]

In addition to the flexible curriculum (flexible), the uniqueness of teaching at the pesantren can also be found in the way of teaching lessons., also in the use of material that has been taught and mastered by the students. Lessons are given in recitation in the form of an open lecture.

In addition, the subjects taught are applicable, in the sense that they must be translated into daily deeds and deeds, of course the ability of the students to apply the lessons they receive is the Kiai's main concern. [9] The learning process is a complex activity, so it is almost impossible to show and conclude that a certain method is superior to other methods in achieving all learning objectives.

The curriculum includes the Koran, hadith, jurisprudence, faith, morals, Islamic history, faraidh (Islamic inheritance), astronomy, the science of hisab, and others. All 
subject matter studied used Arabic books which are commonly referred to as yellow books, bald books, classical books, or turats books. The mandatory books in salaf pesantren include Ihya Ulumiddin (tasawuf), Sahih Bukhari and Sahih Muslim (hadith), Tafsir Jalalain, Alfiyyah Ibnu Malik (nahwu) with their syarah variant, and others.

Pesantren as an educational institution is a system that has several subsystems, each sub-system has several sub-systems and so on, each sub-system with other subsystems influences each other and cannot be separated. The subsystems of the pesantren education system include: (1) Actors or actors: Kiai, ustaz, santri and administrators; (2) Hardware facilities: mosque, cleric house, ustaz house and dormitory, boarding school and boarding school for students, school or madrasa building, land for agriculture and others; and (3) Software facilities: Objectives, curriculum, books, assessment, rules, libraries, information centers, skills, community development centers, etc. [10]

above, then called the boarding school are educational institutions that teach one's piety and learning of sciences of Islam (tafaqquh fiddin) that characterizes and values that are taught in schools.

\subsection{Parenting Students in boarding}

In the Big Indonesian Dictionary, pattern means style, model, system, work method, form (structure) are fixed. [11] Fostering which means nurturing, caring for, caring for, nurturing, educating. [12] Parenting means the attitude of parents in dealing with their students, this attitude can be seen from various aspects, including from the way parents treat students, how to give rewards and punishments, how parents pay attention or respond to students. [13]

According to Sri Lestari, parenting is a series of attitudes shown by parents to students to create an emotional climate that surrounds the interaction between parents and students. [14] Furthermore, Khon, as quoted by Zizousari and Chan, stated that parenting is a way for parents to interact with students which includes giving rules, gifts, punishment, giving attention, and parents' responses to each student's behavior. [15]

In the context of the parenting patterns of students in Islamic boarding schools, the boarding school care is a development and personality development as well as mastery of knowledge that is carried out through daily experiences and is influenced by learning resources in the Islamic boarding school, especially from caregivers. According to Moh. Shohcib stated that the concept of parenting is an effort used to understand, interpret and discover the meanings contained in developing the basic values of the santri / santriwati. Efforts are made through training, habituation and awareness for students. [16] Djamarah states that the concept of parenting is building harmonious communication and implementing educational functions to foster the potential of students as a vehicle for transferring values and agents of cultural transformation. [17]

The pattern of parenting for students is learning about patterns of behavior, socialization and interaction to transfer values and cultural transformation agents in Islamic boarding schools. The Islamic boarding school itself is an educational institution that teaches one's piety and learning Islamic religious sciences (tafaqquh fiddin) which are the characteristics and values that are taught in the pesantren. So, the pattern of caring for students in Islamic boarding schools is the guidance and development of the personality and mastery of knowledge of the students through daily experiences and is influenced by learning resources in the Islamic boarding school, especially from the pesantren caretakers. 
From some of the opinions presented above, the authors conclude that the parenting patterns Students in pesantren are learning about patterns of behavior, socialization and interaction to transfer values and agents of cultural transformation in Islamic boarding schools.

There are 4 aspects of parenting, namely: 1) Supervision (control), namely the efforts of the pesantren caretakers to supervise and influence the activities of the students; 2) communication between pesantren and santri caregivers; 3) Discipline that is applied with a function as a guide in assessing the behavior of students; and 4) Punishment and reward.

\section{Research Results And Discussion}

\subsection{Profile of the Riyadlul Jannah Islamic Boarding School}

Riyadlul Jannah located in Binong Village, Babakan Village, Ciseeng District, Bogor Regency. This Islamic boarding school has been established recently, because KH. Muhammad Supriadi on May 2, 1994 on the idea of H. Syamsudin. With 350 santri residents, Riyadlul Jannah was built to produce preachers or preachers. This special training by prioritizing various da'wah materials such as the Koran and hadiths and their interpretations, understanding the various qoul-qouls of the scholars and their differences, the art of rhetoric, vocal processing, public speaking, and others.

KH. Muhammad Supriyadi AM. born in Jakarta, June 8, 1966, he was born to H. Ammirudin and $\mathrm{Hj}$. Marwiyah has nine siblings, after graduating from elementary school in South Jakarta then Nyantri at the Darul Qalam boarding school Gintung Balaraja, Tangerang for six graduation in 1987 he continued studying at Ibnu Khaldun until 1991 then he devoted himself to Darul Ulum Lido Bantar Kemang Islamic Boarding School for three. To add to his experience in the field of Islamic boarding schools, he continued his service at the Jakarta Assidiqiah Islamic Boarding School, led by KH. Nur Muhammad Iskandar SQ for three years. And during his dedication, he wrote two books, namely, the Da'wah Book through the Islamic Boarding School and the book Majmul Aurad (for the students themselves).

Riyadlul Jannah Islamic Boarding School does not only equip students with religious and general knowledge. But educating them to become believers, have good character, muttaqien and rashikiin fil ilmi and always guide their students to live a simple life pattern in various ways by prioritizing the spirit of hospitality. 


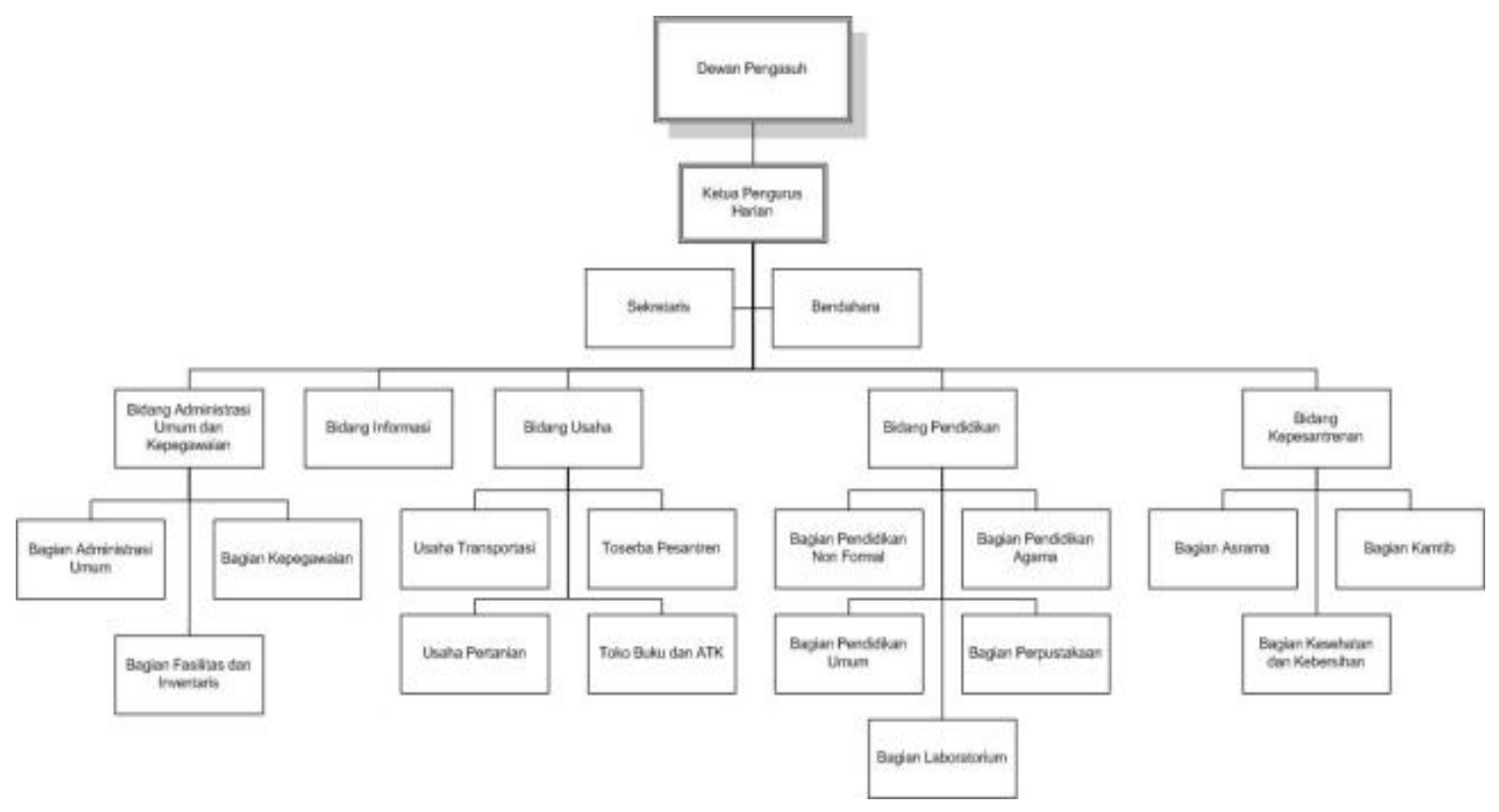

Fig. 1. Organization Structure of Riyadlul Jannah Islamic Boarding School

\subsection{Vision, and Mission, and Purpose of Riyadlul Jannah Islamic Boarding School}

The vision of Islamic boarding school is: Creating smart, skilled, confident students, capable of self-control and able to carry out the mandate of the people and be responsible for society. " Building education that is moral, modern, open, religious, knowledgeable and upholds the cultural values of the nation and Pancasila as a good medium for Islamic da'wah.

Its missions are: 1) Assisting the government in educating the nation's life, 2) Assisting the government in equal distribution of learning opportunities, 3) Fostering Muslims in understanding Islamic teachings and developing as people who believe and fear Allah SWT, so that they have: Akhlakul karimah, Knowledge and skills, physical and spiritual health and a sense of responsibility for the future of religion, homeland and nation.

Medium Objectives: 1) Educate students who have strong faith and devotion to all the truths of Islamic teachings that were revealed to the Prophet Muhammad SAW, 2) Educate students who have noble character, do good deeds, are smart, skilled, and have a sense of responsibility for the future people and the nation, 3) Educate students to be able to think logically based on science and technology and be able to develop in the wider community and maintain the characteristics of Islam and school values inside and outside the school.

\subsection{Facilities and Infrastructure}


To support the process of teaching and learning activities at the Riyadlul Jannah Islamic Boarding School, school facilities and infrastructure have been fulfilled, among others. To support the process of teaching and learning activities at the Riyadlul Jannah Islamic Boarding School, school facilities and infrastructure have been fulfilled, including: 1) School Building and Room the class is built on two floors each level with funding from the Government and donations from several parties. 2) Libraries, Reading Gardens are a mainstay of means to build students' independence in learning. Riyadlul Jannah Islamic Boarding School has 3000 reading books in the school library. Each student is always directed to library exploration activities when given a scientific assignment by the teacher. The books in the Riyadlul Jannah Islamic Boarding School library are classified into several categories, among others; Children's Reading, Literature, General Sciences, Pure Sciences, Applied Sciences, Socio-Culture, and several magazines and print media. 3) ICT room, advances in technology, information, and computers are important. Riyadlul Jannah Islamic Boarding School since 2010 has developed various technology-based approaches to students. Computer training and courses have also been carried out to develop students' competency knowledge of developments and advancements. With adequate facilities, Riyadlul Jannah Islamic Boarding School built an ICT room that will support student activities in terms of; Development of ICT knowledge, completion of final assignments, writing of scientific works. 4) Sports facilities, it is important to explore the potential, interests and talents of students, Riyadlul Jannah Islamic Boarding School has and is currently building several sports facilities, including: Football Field Basketball, Volleyball, Badminton, Table Tennis, and futsal. In 2013, the Riyadlul Jannah Islamic Boarding School is building a multi-functional field as an effort to fulfill sports facilities in schools. And this year, it is planned; The multi-functional field will be completed in October 2013. The target of completing the construction of a sports facility in the form of a multi-functional field is an effort to exercise students, and to get students closer to the sport they are interested in. Apart from the multi-functional field development, the school has also designed several sports and arts activities such as; Chess, Marawis and Theater. 4) Mosque and Musholla, Riyadlul Jannah Islamic Boarding School is one of the educational institutions under the Riyadlul Jannah Islamic Boarding School Foundation. The development of religious facilities and infrastructure is the main priority of this school. Except for the fulfillment of facilities and infrastructure, this educational institution also develops religious activities for students such as; Routine recitation, routine congregational prayers, and other activities. This religious activity is centered at the Jami Mosque in the Riyadlul Jannah Islamic Boarding School Foundation. 5). Internet / Wi-Fi connection, to facilitate communication and fulfill the availability of information, since its inception, Riyadlul Jannah Riyadlul Jannah Islamic Boarding School has utilized the internet as one of the communication infrastructures for school residents. Riyadlul Jannah Islamic Boarding School Riyadlul Jannah has an official website with the address; https://riyadluljannah.id , the provision of this website to facilitate the search for information about schools for school residents and for environments outside the school. The school has also built a free wireless internet (Wi-Fi) network that can be used by boarding school residents

\subsection{Education Services}


The Riyadlul Jannah Islamic boarding school provides formal and non-formal education. Formal education starts from TK / RA, Madrasah Ibtidaiyah (MI), Madrasah Tsanawiyah (MTs), Madrasah Aliyah (MA). Meanwhile, non-formal education is TPQ, Majelis Taklim, Madrasah Diniyah, which can then be described as follows:

Table 1. Table of Education Services at PP Riyadlul Jannah

\begin{tabular}{|c|c|c|c|c|c|c|c|c|c|c|c|c|}
\hline \multicolumn{12}{|c|}{ Educational Services } & \multirow[t]{2}{*}{ Information } \\
\hline \multicolumn{2}{|c|}{ TK/RA } & \multicolumn{2}{|c|}{ MI } & \multicolumn{2}{|c|}{ MTs } & \multicolumn{2}{|c|}{ MA } & \multicolumn{2}{|c|}{ MADIN } & \multicolumn{2}{|c|}{ TPQ } & \\
\hline Lk & $\operatorname{Pr}$ & $\mathrm{Lk}$ & $\operatorname{Pr}$ & Lk & $\operatorname{Pr}$ & $\mathrm{Lk}$ & $\operatorname{Pr}$ & $\mathrm{Lk}$ & $\operatorname{Pr}$ & $\mathrm{Lk}$ & $\operatorname{Pr}$ & \\
\hline 15 & 29 & 64 & 43 & 120 & 77 & 93 & 66 & 30 & 11 & 15 & 20 & \\
\hline \multirow{2}{*}{\multicolumn{2}{|c|}{44}} & \multicolumn{2}{|c|}{107} & \multicolumn{2}{|c|}{197} & \multicolumn{2}{|c|}{159} & \multicolumn{2}{|c|}{41} & \multicolumn{2}{|c|}{35} & 583 \\
\hline & & & & \multicolumn{4}{|c|}{504} & & & & & $\begin{array}{l}\text { The number of } \\
\text { students who are } \\
\text { cared for by }\end{array}$ \\
\hline
\end{tabular}

The Superior Program of the Riyadlul Jannah Ciseeng Islamic Boarding School, Parung Bogor

a. Muhadoroh Program. Muhadoroh is learning to speak in front of an audience or a crowd and also giving speeches, this program is learning that is used mostly in formal and nonformal Islamic education and also Islamic boarding schools for To train students and students to be accustomed to speaking in front of things that are feasible or public, because of that the santri's capital will go to the community to preach, that is what he learned at the pesantren and this is applied at the Riyadlul Jannah Islamic Boarding School. This program is carried out by students every Friday and Saturday, Friday night and Saturday night when the evening prayers, this program has been very good for producing students to become accustomed to speaking in front of an audience or also accustomed to making speeches.

b. The Yellow Books Learning Program. Pesantren as a traditional Islamic educational institution teaches classical books, especially books written by the Syafi'iyah school of thought. Teaching yellow books in Arabic without shakal or often called the book bald. This yellow book is one of the methods formally taught in the Salaf pesantren community. And at the Riyadlul Jannah Islamic Boarding School, it combines modern and traditional concepts and therefore continues to study yellow books. The guidebooks studied by the santri.

\section{Pattern of Nurturing the Santri at the Riyadlul Jannah Islamic Boarding School}

The dominant parenting patterns applied in the Riyadlul Jannah Islamic boarding school are democratic patterns on the teaching aspect, authoritarian patterns on the reward aspect, and persuasive patterns on the persuasion aspect. Teaching is carried out with learning activities, both intra and extra. Reward is done by giving awards for the achievements achieved by the students and giving punishment for violations that have been committed. Persuasion is carried out through a personal approach by providing advice, directions, guidance to the students, and helping in solving problems being faced by the students. So that Riyadlul Jannah Islamic boarding school students do not have bad behavior and bully their friends / friends and their 
underclassmen. Therefore, the caregivers have taken various steps to take care of the santri at the Riyadlul Jannah Islamic boarding school, including:

a. Strengthening the curriculum. The curriculum is taught in accordance with the vision and mission, namely strengthening material on tawhid, faith, worship, and morals. The delinquency of the students is not an obstacle for every caregiver who has high enthusiasm in developing the faith, worship, and morals of his students. Meanwhile, in minimizing the delinquency of the students every month, the boarding school provides additional material relating to juvenile delinquency provided by the health office, social services and the police.

b. Early Detection of Santri Psychology. One of the caregivers' responsibilities is to study the psychology or psychology of students. Students who have a high temperament / easily get emotional will be given special guidance. Likewise, the students who feel inferior and unable to get along with their friends will prefer to be alone by reading books and fantasizing.

c. Enforcement of the rules. Students who violate will be subject to sanctions in accordance with the applicable rules. Heavy and repeated violations will be accumulated, and as a final step is to summon the parents of the santri concerned, to choose whether their child will remain in the pesantren or be expelled. So, the pesantren does not immediately choose an alternative to expel the students. However, ask for advice from the parents or guardians of the santri concerned.

d. Practicing the disciplinary. Discipline established by the Riyadlul Jannah Islamic Boarding School is quite strict. This is so that they can learn discipline from an early age and get used to taking responsibility. The disciplinary model applied by the pesantren does not provide opportunities for students to mingle with groups outside the pesantren that can doctrine them. to mingle with groups outside the pesantren who doctrine them.

e. Providing various kinds of sports and skills facilities. So that the students can channel and develop their talents, the pesantren provides various kinds of sports facilities and skills. One of the reasons for people to do wrong is because of poverty, unemployment. This is because they do not have a job that can help them live, in addition, because they do not have skills, so their minds are confused and always confused. Eventually frustrated and doing actions that can harm himself and others.

f. Religious Lectures. Basically, the caregivers are not fixated on the formal lectures that have been programmed by the pesantren, they also give advice to the students wherever possible when they are in the scope of the dormitory or pesantren in general. Therefore, the pesantren held activities by providing opportunities for direct dialogue with their students about issues concerning Islam that were in the minds of every student, namely after each dawn and noon prayer every Monday and Thursday. However, it does not rule out that at other times the santri are also allowed to raise their problems

g. Prohibition of using HP. Santri are prohibited from using cellphones during learning activities so that students do not have much contact with the outside world which can interfere with their learning concentration, including communication with people suspected of having a negative influence. According to the caretakers of the cellphone, there are many negative things for the santri, while the santri in their adolescence cannot use cellphones in an educational manner, they instead follow what is on the cellphone without being able to sort out what is good and right. And they can use their cellphones once a week and are only given 4 hours. After that the cellphone is returned again to the cellphone custody 
h. Enjoy television broadcast once a week. To get rid of the boredom of the students, as well as to eliminate fatigue from studying for a week, on Friday nights the students are allowed to watch television after sunset prayers, accompanied by the guardian of their dormitory. The large number of immoral shows shown on TV requires caregivers to be observant in choosing each program that will be presented to the students. Of course, this choice has educational value for the development of the IQ of the students. Not only choosing a good program, the caregiver also explains things that are still vague about the event. Describe the benefits of the event compared to other events. Explanation is needed because not all students have the same catching power. To get rid of the students' boredom, and at the same time relieve fatigue from studying for a week, on Friday nights students are allowed to watch television after sunset prayers, accompanied by the guardian of their dormitory. The large number of immoral shows shown on TV requires the caregivers to be observant in choosing every program that will be presented to the students. Of course, this choice has educational value for the development of the IQ of the students. Not only choosing a good program, the caregiver also explains things that are still vague about the event. Describe the benefits of the event compared to other events. Explanation is needed because not all students have the same catching power.

Meanwhile, to find out the extent of the santri's delinquency at the Riyadlul Jannah Islamic boarding school, 30 questionnaires were distributed with indicators of student delinquency including lying, stealing (taking belongings of friends), hitting, fighting with friends, making fun of friends, smoking, drugs. Each level is taken 10 students, with 10 statements in each indicator, for more details can be seen in the diagram below.

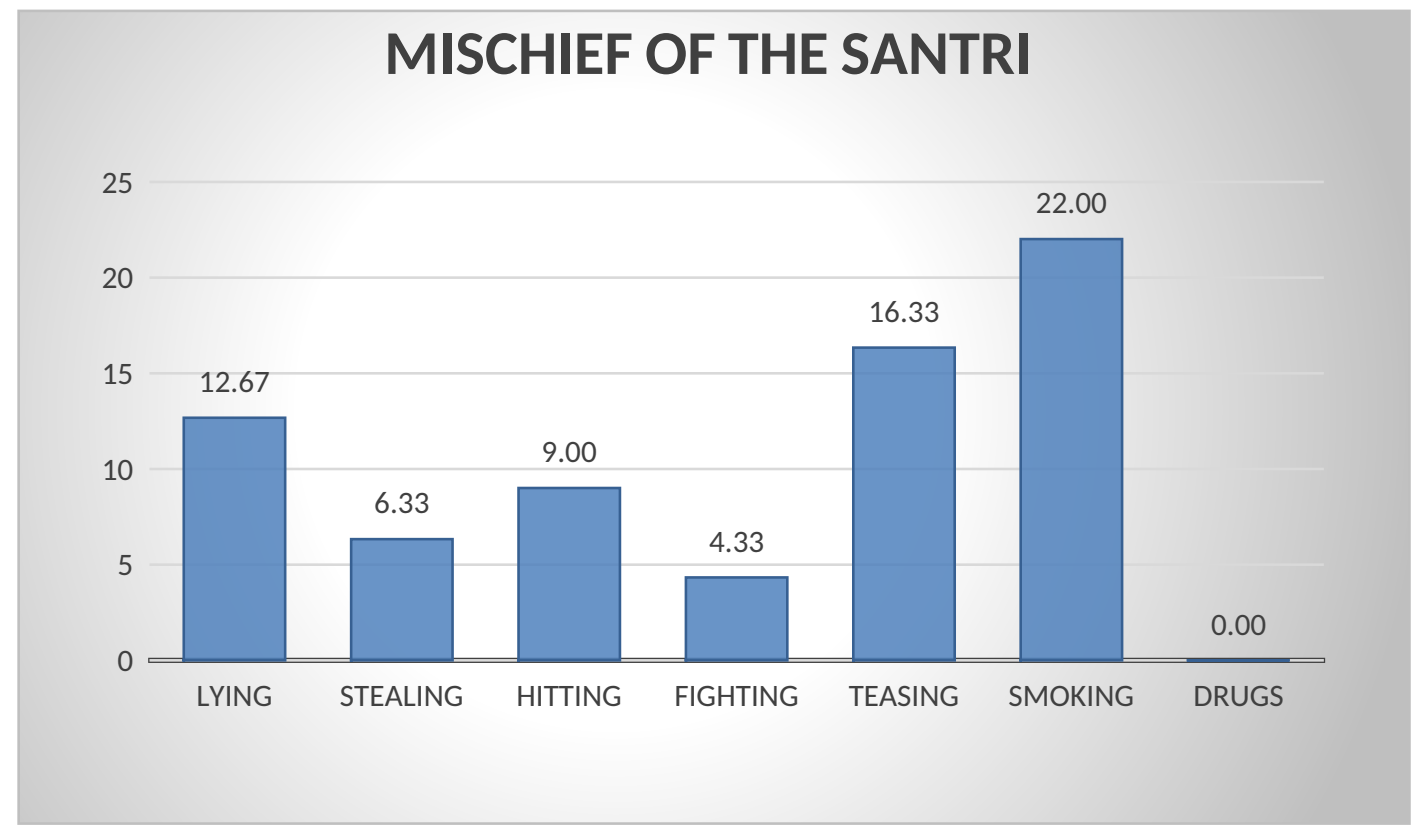

Fig. 2. Mischief of The Santri

From the diagram above, the low percentage of responses is understandable or considered reasonable, considering the number of students being cared for is 504 students. According to 
Ustadz Rahmat Hidayat, that the pesantren prohibits students from smoking, but there are some students who smoke secretly in the bathroom.

\section{Supporting and Inhibition Factors in the care of students}

Some of the supporting and inhibiting factors in the parenting patterns of the students in the two pesantren are:

a. Supporting Factors. Supporting factors for the Riyadlul Jannah Islamic Boarding School so that the public still has great interest in the pesantren: a). The interest and trust of parents is still high in sending their children to Islamic boarding schools. The level of public trust in the world of pesantren is still high. This is because the community still believes that the accusations against the pesantren are untrue and are only based on the number of pesantren alumni involved in terrorism, whose number can be counted on the fingers. b). Strict rules. The regulations applied by the pesantren are very strict, accompanied by penalties for violating them. Various kinds of rules have been made and have been socialized since the first students set foot in the pesantren, so that they do their best to comply with these rules. Among the efforts that can prevent santri delinquency understanding is that each student must be picked up by their parents or their closest relatives who are already known to the pesantren manager. c). The curriculum on monotheism, morals, and worship material is still maintained as a characteristic of pesantrenan material. The pesantren curriculum is one of the important factors in shaping the character of the students. Therefore, Riyadlul Jannah Islamic boarding school still maintains the material of monotheism, morals and worship as the characteristics of pesantrenan material, d). Compact the schedule of activities for students. The tight schedule of the students makes them must be diligent and disciplined and follow directions and caregivers. They are busy with various activities day and night, so that access to the outside world is not easy. This can prevent them from outside influences that can change their religious paradigm, e). There is still a high attitude of respect for students to caregivers, so that what the students do can still be controlled. The pesantren emphasizes the importance of respecting caregivers who are identified as the relationship between children and their parents. Good caregivers position themselves as parents who always pay attention to their children. Respect for students will give birth to an attitude of obedience making it easier for the caregiver to control the students, f). The spirit of the caregivers is still high in educating, especially in the development of faith, worship and morals. The delinquency of the students is not an obstacle for every caregiver who has high enthusiasm in developing the faith, worship and morals of his students, g). There are still high examples of role models shown by the caregivers to the students. The nannies are role models for the students. By always giving good role models, santripun will always have good morals as their caretakers, h). Recreation To eliminate the boredom of the students, at certain times such as after semester exams, the students and caregivers take recreation to various places, such as museums and baths. However, the recreation is still controlled by the caregivers so that negative things can be avoided. These are some of the supporting factors possessed by Riyadlul Jannah Islamic Boarding School, so that the pesantren still exists today in society.

b. Inhibiting Factors. Apart from supporting factors, there are also inhibiting factors that sometimes-become obstacles for pesantren in implementing the parenting patterns they run. Among the inhibiting factors, namely: a) The element of parental coercion. There are 
still parents who force their children to enter the pesantren, causing children who are not motivated to accept lessons, pessimistic, undisciplined, impatient, and always create chaos in the pesantren. The incompatibility of children's tendencies in what they do can cause children to drop out of school or be expelled from the pesantren because they do not heed the applicable regulations. They deliberately do negative things that can affect their other friends so that it will become a burden to the pesantren caretakers, b). Parents' interference with pesantren rules. The intervention of the parents was seen when the child was punished for the offense he had committed, because the child did not accept the punishment, the students complained to the parents. It is not uncommon for parents to respond by sending objection letters, or parents go directly to the caregiver who has given punishment to their child at the pesantren. c). Human resource development for caregivers has not been optimal. Increasing the human resources of caregivers greatly affects the students. In addition to the bonds of educational qualifications from $\mathrm{S} 1$ to $\mathrm{S} 2$ and $\mathrm{S} 3$, it is also necessary to obtain various kinds of knowledge about parenting patterns, d). Lack of good cooperation between caregivers. Parenting should be a shared responsibility of all elements of the pesantren. The need for understanding parenting patterns is also important so that students are not confused, if they find different patterns between caregivers. These are some of the obstacles experienced by the pesantren so that the pesantren is still a little under control in implementing the parenting patterns and the aspects it develops in order to anticipate the delinquency of the students in the pesantren.

c. Efforts to Overcome Obstacles. The efforts to anticipate the obstacles experienced by the Mukminin Islamic Boarding School and the Medina Islamic Boarding School are as follows. a) Parents provide a good understanding to children about the privileges of the pesantren. Every parent must provide a good understanding to their children before they enter their children into Islamic boarding schools. This is so that children do not feel compelled to enter the pesantren. Giving this understanding will also instill love for children by explaining the features of pesantren graduates as provisions for them when they set foot in college. Thus, the involvement of the parents of students in anticipating the obstacles experienced by the pesantren is necessary. b) Socializing the rules of the pesantren to parents of students. Parents' interference with the punishment that befell their children because they do not know clearly the rules that are enforced at the pesantren. For this reason, it is important for the school to socialize all the rules that apply in the pesantren to each santri's parents when they enroll their children in the pesantren. c) Increasing human resources for caregivers, through trainings. Along with the times, juvenile / santri delinquency has increased with various models and forms. For this reason, it is necessary to increase human resources for caregivers through various kinds of training, so that they can understand the problems being faced by students and how to overcome them. D) Foster good cooperative relationships between caregivers. Cooperation between caregivers is very important because naughty santri tend to seek legitimacy or justification for their actions that other caregivers do not prohibit them. For that every caregiver must understand the parenting patterns that are applied in the pesantren. in the pesantren to each of the santri's parents when they register their children at the pesantren, c). Increasing the human resources of caregivers, through trainings. Along with the times, juvenile / santri delinquency has increased with various models and forms. For this reason, it is necessary to increase human resources for caregivers through various kinds of training, so that they can understand the problems being faced by students and how to overcome them, d). Foster good cooperative relationships between caregivers. Cooperation between caregivers is very 
important because naughty santri tend to seek legitimacy or justification for their actions that other caregivers do not prohibit them. For that every caregiver must understand the parenting patterns that are applied in the pesantren.

\section{Conclusion}

Based on the previous description, it can be concluded as follows:

a. The pattern of caring for the Riyadlul Jannah Islamic Boarding School applies a parenting pattern that is democratic from the teaching aspect, authoritarian from the teaching aspect and persuasive from the persuasion aspect. Teaching is given through intra, extra-curricular activities, giving examples to students in the form of behavior, characteristics, attitudes, and ways of thinking. Reward through reward or motivation and punishment. Rewards are in the form of gifts and praise, while punishment is in the form of sanctions as a result of acts and actions that violate applicable rules. Starting from light punishment (advice) to severe (expelled from the pesantren). Persuasion is done by giving advice through an individual approach to help students solve their problems. Gentle advice is expected to return the students to the right path. The difference between the two can be seen from the following aspects: a) Teaching: The Riyadlul Jannah Islamic Boarding School applies a general, religious curriculum, but teachings and understandings that are in line with NU are inserted when the kiai teaches and practices worship followed by the students. Santri do not know how NU's history, goals, vision, mission are fundamentally. The books used still use more classical books by introducing more of the understanding of the Shafi'i school of thought. b) Reward: The Riyadlul Jannah Islamic boarding school in applying the rules of violation is orderly and structured. There is a weighted value for each violation committed. It depends on the error rate. Likewise, the stages of punishment are always carried out with predetermined stages.

b. Due to the effectiveness of the parenting style applied at the Riyadlul Jannah Islamic boarding school, the students' delinquency could still be overcome, even though there were also students who were naughty by nature. Of the 30 questionnaires spread, with various answers including: lying (12.67), stealing (taking a friend's property (6.33), hitting (9.00), fighting with friends (4.33), making fun of friends (16.33), smoking (22.00), and drugs (0.67). Supporting factors for the implementation of the pesantren's pesantren parenting patterns are still able to anticipate the delinquency of the students, namely; The high interest and trust of parents to enter their children into the pesantren. The rules imposed by the pesantren make students afraid to violate because there are sanctions behind the violations. The curriculum on monotheism, morals, and worship is still maintained coupled with extra material about juvenile delinquency and its consequences. opportunity to do the anarchists. the high attitude of respect for the students to caregivers so that what is done every time the students still can be controlled. However, the enthusiasm of some caregivers is high in educating, especially in the development of faith, worship, and morals. There are still high examples of role models shown by caregivers to students, so that students can still see good things from their caregivers. Meanwhile, the inhibiting factors in implementing aspects of parenting patterns are the element of coercion from parents to send their children to the pesantren. Lack of supervision of students when they are outside the pesantren. There are still parents who object if their children are punished. Human resource development for caregivers is not optimal. Lack of good cooperation between caregivers. 
c. The efforts to overcome the obstacles faced by caregivers in implementing parenting patterns include; parents should provide a good understanding to children about the privileges of the pesantren, the socialization of pesantren rules to the parents of students and the care must be continuous and integrated. Meanwhile, the most effective parenting steps are carried out by teaching tauheed and morals accompanied by close supervision of the students. Apart from that, the students are busy with various activities, both intra and extra-curricular activities. The steps that need to be developed as a support, including; Intensifying the socialization of moderate religious understanding. Reference supplies or collections of humanist Islamic books in the library. Adding special material about the dangers of delinquency in students. Straighten the meaning of jihad. Early selection of psychiatric disorders of the students. Building the independence of students by providing various kinds of skills. Building a network of cooperation between Islamic boarding schools, it is also demanded that caregivers have broad religious insight and the need for selectivity in the recruitment of teaching staff.

\section{Recommendation}

1. Pesantren need to optimize the implementation of guidance and supervision of students continuously so as to create child-friendly pesantren.

2. Pesantren need to create awareness of students to obey, obey the rules and discipline that apply

3. Pesantren need to collaborate intensively between teachers, parents and related parties in guarding the development of student learning and being in the boarding school dormitories.

4. People who entrust their children to Islamic boarding schools should be able to trust and have more confidence in the patterns of education carried out by the pesantren. 


\section{References}

[1] Ali, K. M., Imtihana, A., Ismail, F., \& Zain, H. (2017). Penerapan Pola Asuh Terhadap Santri Di Pondok Pesantren Al-Amalul Khair Palembang. Tadrib, $3 / 2$.

[2] Munawiroh. (2012). Pengajaran Kitab Kuning Di Pondok Pesantren Madarijul Ulum. EDUKASI: Jurnal Penelitian Pendidikan Agama Dan Keagamaan, 10.

[3] Dhofier, Z. (1982). Tradisi Pesantren: Studi Tentang Pandangan Hidup Kiai. LP3ES.

[4] Kuntowijoyo. (1995). Pengantar Ilmu Sejarah. Yogjakarta:Benteng Budaya.

[5] Shochib, M. (1998). Pola Asuh Orang Tua dalam Membantu Anak. Mengembangkan Disiplin Diri. Jakarta:Rieneka Cipta, 36.

[6] Tim Pengembang Ilmu Pendidikan. (2007). Ilmu dan Aplikasi Pendidikan Bagian III. Bandung: FIPUPI, 453.

[7] Munawiroh. (2012). Pengajaran Kitab Kuning Di Pondok Pesantren Madarijul Ulum. EDUKASI: Jurnal Penelitian Pendidikan Agama Dan Keagamaan, 10.

[8] Arifin Imron. (1995). Kepemimpinan Kiai: Kasus Pondok Pesantren Tebuireng Jombang.

[9] Dhofier, Z. (1982). Tradisi Pesantren: Studi Tentang Pandangan Hidup Kiai. LP3ES.

[10] Ahmad Syahid (edt). (2002). Pesantren dan Pengembangan Ekonomi Umat.

[11] Tim Redaksi. (2013). Kamus Besar Bahasa IndonesiaPusat Bahasa,. Jakarta: PT. Gramedia, 2013, 1088.

[12] Tim Redaksi. (2013). Kamus Besar Bahasa IndonesiaPusat Bahasa,. Jakarta: PT. Gramedia, 2013, 1088.

[13] Mahmud. Heri Gunawan dan Yuyun Yulianingsih. (2013). Pendidikan Agama Islam dalam Keluarga,. Jakarta: Akademi Permata, 150.

[14] Sri. (2012). Psikologi Keluarga: Penanaman Nilai dan Penanganan Konflik dalam Keluarga,. Jakarta:Prenada Media Group, 50.

[15] Zizousari dan Yuna Chan. (2016). Working Mom is Super Mom, bagaimana Membagi Antara Keluarga dan Karier,. Yogjakarta: Trans Idea Publising, 14-15.

[16] Shochib, M. (1998). Pola Asuh Orang Tua dalam Membantu Anak. Mengembangkan Disiplin Diri. Jakarta:Rieneka Cipta, 36

[17] Djamarah, B. S. (2005). Pola Komunikasi Orang Tua \& Anak Dalam keluarga. Jakarta: PT. Reneka Cipta, 2-3.

\section{Informants}

1. KH. Muhammad Suryadi, (Pimpinan Pondok)

2. Ustaz Rahmad Hidayat, 50 Tahun (Ketua Pengasuhan)

3. Ustaz Defri Hamdani 45 Tahun (Pengurus Bidang kepesantrenan)

4. Bakri, 53 Tahun (Penyuluh Agama Islam Kab. Bogor)

5. Wahyu widayat, 17 Tahun (Santri) 